IP Periodica Polytechnica

Social and Management

Sciences

25(1), pp. 49-55, 2017

DOI: $10.3311 /$ PPso. 8850

Creative Commons Attribution (i)

RESEARCH ARTICLE

\section{An Investigation of Property Value Impairment Caused by Noise, in the Case of the Budapest Ferenc Liszt International Airport, Using a Hedonic Model}

\author{
István Hajnal ${ }^{1 *}$
}

Received 27 November 2015; accepted after revision 15 November 2016

\begin{abstract}
The issue of the value impairing impact of airports on nearby properties has been studied in the technical literature for decades. There is quite a wide consensus on the fact that in North America and Western Europe, the increasing noise pollution caused by airports leads to reduced property values: in general, each $1 \mathrm{~dB}$ growth in noise level leads to a 1\% drop in property value. The purpose of this study is to find a correlation between noise levels and property value impairment (if any), based on the limited amount of available data, with regard to Budapest Ferenc Liszt International Airport (BUD). The examination described in this paper was conducted applying the commonly-used hedonic model, and, even though this study could not prove the correlation, it designates the direction in which necessary database-building and future research should be conducted.
\end{abstract}

\section{Keywords}

airport noise, market value, value impairment

\footnotetext{
${ }^{1}$ Department of Construction Technology and Management, Faculty of Architecture, Budapest University of Technology and Economics H-1111 Budapest, Müegyetem rakpart 3, Hungary

*Corresponding author, e-mail: drhajnali@gmail.com
}

\section{Introduction}

As a result of the extraordinary demands of the explosively developing tourism industry, airports are the infrastructural facilities that are being developed the most intensely these days. However, airports impose concentrated load on the environment, and we should be aware of - and possibly control - its further consequences. Noise pollution is the aspect of the environmental load imposed by airports on nearby areas that has the most serious impact on the inhabitants. Noise pollution causes environmental harm to people living near the airport, and, indirectly, it causes a loss of value to their properties as well. This value impairing impact has been examined widely for a long time in international technical literature. However, no such research has been published in Central Europe so far. This study is intended to fill this gap, relying on the limited amount of available data. We are aware that a significant amount of further data and fine-tuning is needed so we can raise local experience to the level of international research results. What make this research topical are the increasing demands of society for sustainability as well as the programme of developing various elements of social infrastructure: a thorough preparation of social decisions is only possible if feasibility studies provide a clear picture on the potential consequences to society and the economy and additional costs in a timely manner.

This study is focused on the value impairment of properties situated in the surroundings of the Budapest Ferenc Liszt International Airport, caused by airport noise. Operated by Budapest Airport Zrt., Budapest Ferenc Liszt International Airport (hereinafter referred to as BUD) is Hungary's largest airport. In 2014, it reached a record 9.156 million passengers in total, and in 2013, there were 82,300 aircraft movement in total. The airport is situated at the southeastern edge of Budapest, 16 $\mathrm{km}$ distant from the city centre. It is surrounded by the roads Ferihegyi Repülőtérre vezető út, Üllői út, the new Ecseri út, Bélatelepi út and Csévéző út. Regarding public administration, the area belongs to the 17th and 18th districts of Budapest, and to the townships of Vecsés and Ecser. The two runways of the airport are built in a parallel but offset pattern. For this reason, the older runway No. 1 (marked 13R/31L) is about 
two kilometres closer to the center of Budapest than the later runway No. 2 (marked 13R/31R). This type of arrangement is called a bayonet system. The building complex of the main terminal is in the centre, i.e. between the two runways. The development of BUD is still uninterrupted today. The development of a multifunctional logistics basis was envisaged at government level to enhance its commercial capacity ${ }^{1}$.

As with every airport, the most significant load BUD imposes on the environment is aircraft noise. However, there are other types of environmental load as well, such as the turbulence generated by the airplanes, air pollution or fear of the sight of moving aircraft. Local property sales experts estimate ${ }^{2}$ the total property value impairment effect of these factors as $25 \%$, and they assume that it actually shows in market prices, but it should be stressed that this estimate lacks any related basic studies. Related studies on the spread of air pollution and noise have already been published in Hungarian technical literature (Kugler et al., 2010; Munkácsy et al., 2010). Studies that were conducted during the full flight ban ordered because of the Icelandic volcano eruption showed that air pollution caused by aircraft is negligible in proportion to background pollution.

\section{Purpose of the investigation; Hypothesis}

Setting up a scientific model is a self-evident solution to confirm or refute various common beliefs, some of which might even be labelled "professional". Especially because extensive and deep research activity has been conducted and documented in international technical literature on this matter, and - among other means - there is a suitable model for the examination, namely the hedonic method. On the other hand, it is clear that the database that would be necessary for the application of this model is only partially available, and it is extremely complicated to gather even the minimum amount of data content that is required for conducting the analysis. Up to this time, the main obstacle to conducting this study was the lack of data. Since the housing market has shifted into the electronic space, this provides a (still limited) opportunity for an attempt to apply the experience found in technical literature to an Eastern European example, i.e. Budapest's international airport.

The market value of properties is shaped by the actors in the market, taking experience and comparison data from previous transactions into account at each transaction. This way, market value will not be shaped from an aggregate of physical parameters but from the impacts thereof, filtered through the subject. In addition, by applying the hedonic model (as will be explained later), it is shown that the impact of noise pollution

1 Gov. Resolution No. 1473/2015 (15 July)

2 "Blighted Apartments: Even if You Sell Them, You can Take a 20\% Loss for Granted." ("Rettegett lakások: ha el is megy, 20 százalékot biztos buksz rajta"); http://www.ingatlanmax.hu/index.php?o=22\&id=175; downloaded on $16 / 10 / 2015$ on the value of a certain property does not depend on the actual noise level but on the subjective view of the affected individuals (Chaso et al., 2012). The subjective feeling of the individual is of key importance in this matter. This is expressed by the Life Satisfaction (LSA) index, which was developed primarily for research related to noise or air quality (Frey et al., 2009). It should be noted that airport noise will not be treated in the same way as noise coming from traffic or other sources. The disturbing effect of aircraft noise is greater, due to its dispersion (Miedema et al., 2001).

Based on the above, the hypothesis of this study is as follows: actors of the housing market (sellers, agents, buyers) take the noise pollution from the airport into account, and they make it appear in the asking prices of the properties. We attempted to justify this hypothesis by conducting a hedonic study of sample areas. The studied area (the town of Üllö) is situated well within the noise area of the airport, which means, it is greatly exposed to airport noise. The control sample area (the town of Gyömrö) falls into the same category in terms of the housing market; however, it is outside the noisy area. There is an average difference of $10 \mathrm{~dB}$ in noise levels which come from aircraft noise between the studied area and the sample area. This means that, based on our hypothesis and on international experience, we should find a significant difference of 8 to $10 \%$ in property values.

\section{Study of technical literature: The value impairment of aircraft noise}

In 1994, a summary overview ${ }^{3}$ of previous related studies was made by the Federal Aviation Administration of the United States (FAA), and, based on these, a recommendation for a new methodology was made. The purpose of the study was to enable decision makers, before building new airports, to assess the expectable additional costs coming from the value impairment affecting property owners due to increased noise levels. For this purpose, a mixed data collection and evaluation method was developed. The study highlights the fact that the value impairment of low-prestige properties is significantly lower than that of high-prestige properties. It was raised as an open question that a possible later decrease in noise levels around airports does not necessarily entail increasing prices. No other (published) research has been conducted on this matter ever since. Later on, several (mostly American) experts have researched the value impairing impacts of airports, always relying on the conclusions of their predecessors. Besides summarising previous experience in a 2001 paper, Bell points out that property renters, and thus rental fees, are less sensitive to increasing noise than to changes in commercial traffic levels, which is related to the criteria of property owners (Bell, 2001). Bell illustrates with diagrams the

3 The Effect of Airport Noise on Housing Values: A Summary Report. Federal Aviation Administration. 1994. 
actions that owners are willing to take in each noise area (legal measures, group protests, individual complaints etc). Nelson (2004) studies 33 previous data aggregations in his article, using a meta-regression model. He experienced that in the area of the USA, a 0.5 to $1.6 \mathrm{~dB}$ increase in noise levels entails a value impairment of $1 \%$. On the other hand, he pointed out that none of the previous studies could handle the elimination of value enhancing impacts of airports, for example, improved accessibility. This factor is also dependent on distance, and, unlike negative effects, it actually increases property values. In another paper, published four years later (Nelson, 2008), he described the modelling procedures for this problem and the related study findings. He arranged potential methods into two clear-cut groups: HP (Hedonic Pricing) and SP (Stated Preference). In 2006, Lazic et al. made an overview of significant analyses that had been made in the USA since 1990, and summarised them for the purpose of synthesis (Lazic et al., 2006). She found that both methods applied by analysts lead to the general conclusion that each $1 \mathrm{~dB}$ increase in noise load entails about $1 \%$ of property value impairment. Jud applied a new approach compared to previous studies: they studied how the announcement of building a new airport would affect housing prices (Jud et al, 2006). By applying the SAR model on a sample size of tens of thousands, the announcement led to a $9.2 \%$ decrease within a 2.5.-mile area of the airport and to a 5.7\% decrease in a further 1.5-mile area, compared to the usual $\sim 2 \%$ discount in the asking prices. However, despite the massively unequivocal standpoint of researchers and their multiple synthesis, results with the opposite outcome appear as well: In his thesis, Valdes (2008) used a method of spatial correlation and didn't find any obvious value impairment in connection with the increase of noise levels at Oakland Airport. Valdes points out that at certain locations and for certain types of properties, a change in the items that constitute value might even lead to an increase in values with regard to an airport. Boes et al. (2010) share a similar opinion when they find that rental fees are not influenced solely by the actual magnitude of noise but also by other, often counteracting, variables that are related to a certain location. They also found that in the area of Zürich Airport, a $1 \mathrm{~dB}$ increase in noise levels led to a $0.5 \%$ decrease in rental fees.

\section{Technical literature: Application of the hedonic model}

The models used for calculating the value impairment of stigmatised properties were summarized by Horváth (Horváth et al., 2014), and they also made a recommendation for the application of these models in various circumstances. Based on this recommendation, the hedonic method is the most suitable in this case. The hedonic model was first extended to the explanation of property values in 1970 (Kain et al., 1970). 39 variables were divided into 5 groups using factor analysis and, for each group, regressive correlations were studied and hedonic formulae were developed for calculating property prices. The point of the hedonic model is that the value of the property is broken down into value items, and a multiplying factor is assigned to each value item, which will represent the weight of each item in the total value as a "shadow price". The usual linear correlation is represented by a formula as follows:

$$
P=\alpha+\sum\left(\beta_{i} * x_{i}\right)+\varepsilon,
$$

where

$\mathrm{P}$ : Value of the property;

$\alpha$ : Constant;

$\beta_{\mathrm{i}}$ : Shadow price of value item No. $\mathrm{i}$;

$\mathrm{x}_{\mathrm{i}}$ : Value item No. $\mathrm{i}$;

$\varepsilon:$ Standard error.

To eliminate an asymmetric development of prices, a logarithmic transformation of variables is often used by applying the following formula (Malpezzi, 2008):

$$
\ln P=\alpha+\sum\left(\beta_{i} * \ln x_{i}\right)+\varepsilon .
$$

The hedonic method has an extensive literature, looking back to a past of about half a century. In contemporary international technical literature, the most research using the hedonic evaluation method has been conducted by Asian researchers. A detailed 2002 critical summary (Chan et al., 2002) found that the housing market can be described by attributes related to location, building structure and environment. For this purpose, the target value is determined using a logarithmic transformation. In this paper, Chan justifies the viability of this model using a homogenous sample consisting of 120 items. Jim et al. (2006) also preferred the logarithmic form when they were studying the value composition of 600 new apartments located in Guangzhou, China.

In Hungary, the principle of the hedonic method was first applied to the housing market by Horváth et al. (2007). Horváth attempted to describe the Hungarian housing market using this model, taking into account factors related to location, quality and size of the properties as well as temporal factors. The Hungarian "House price index", which was developed by his workgroup, is also based on this methodology.

Similar problems to those of this study have been researched using the hedonic method. For example, Thamrongsrisook (2011) drew up a similar multiple regression model for the value enhancing impact of the Bangkok underground network, which justified the hypothesis (i.e. the proximity of the underground will enhance the value of properties) at certain locations. Hajnal studied the value impairing impact of telecommunication transmission towers using a hedonic approach in his work marked (Hajnal, 2012). Some researchers set the goal of fine-tuning hedonic variables. For example, Herath found that the usual "Bus stop within 400 meters" value enhancing factor hadn't brought any significant change (in the Sydney sample he studied), while 
it was clearly shown in the transaction prices that the "Bus stop within 200 meters" attribute enhances property values by $6.8 \%$ (Herath, 2015). Morancho also applied a hedonic model in Barcelona (Morancho, 2003), and experienced that, in the model of the transaction price, out of the environmental factors, only the distance to a green park appears, regardless of the size of the park. As we have previously seen, hedonic model analyses have been conducted for the value impairing impact of aircraft noise, too (Nelson, 2004; Nelson, 2008; Boes et al., 2010).

\section{Data collection and processing}

We chose the family house areas of two very similar settlements for our hedonic study. In the sample area procedure, we presume that the value conditions of the two settlements are the same, and the only difference comes from the noise load. In the case of BUD, the surrounding settlements are quite different regarding location, available transportation or other attributes; the two most similar settlements are Üllö and Gyömrö. The population of Üllö is 11,600, while the population of Gyömrö, the sample area, is 16,700 (2014 data). Both settlements are located in the southeastern agglomeration of Budapest. The distance between their town centres is about $7 \mathrm{~km}$. The attributes regarding accessibility and available transportation are very similar in the case of both settlements, in relation to the whole agglomeration These are typical "commuter towns"; the housing market revolves around commuters to a great extent ${ }^{4}$. The housing markets of both towns show signs of awakening after the recession, which also shows in the increasing number of advertisements. Both towns are located at plain areas, with well-developed town centres and widely dispersed town structures. The arrangement of buildings is typically suburban style; semi-detached houses are quite typical of both settlements (this is a common feature of Hungarian "commuter towns"). The biggest difference between the two settlements is the one relevant for our study: Üllö falls within the noise area of BUD, while Gyömrö doesn't. This mean that the noise levels the properties in Üllö are exposed to are 5-10 dB higher than those in Gyömrő. The designation of a so-called noise-barrier zone around BUD has been in progress for years now as per relevant law ${ }^{5}$ but it has not been finished yet. The noise isophones published by the settlements and BUD in 2014 are shown in Fig. 1. As can be seen in the picture, Üllo falls within the aircraft routes, while Gyömrö is outside of this range. This means, as per our hypothesis, the value impairing impact is constituted not only by higher noise levels but the visual effect, i.e. the sight of aircraft, as well.

4 "Migration and the Housing Market in the Agglomeration of Budapest" ("Migráció és lakáspiac a budapesti agglomerációban.") https://www.ksh.hu/ docs/hun/xftp/idoszaki/regiok/bpmigracio.pdf, downloaded on 16/10/2015.

5 Gov. Decree No. 176/1997. (11 October) On the designation, utilisation and abolition of noise barrier zones to be implemented in the surroundings of airports

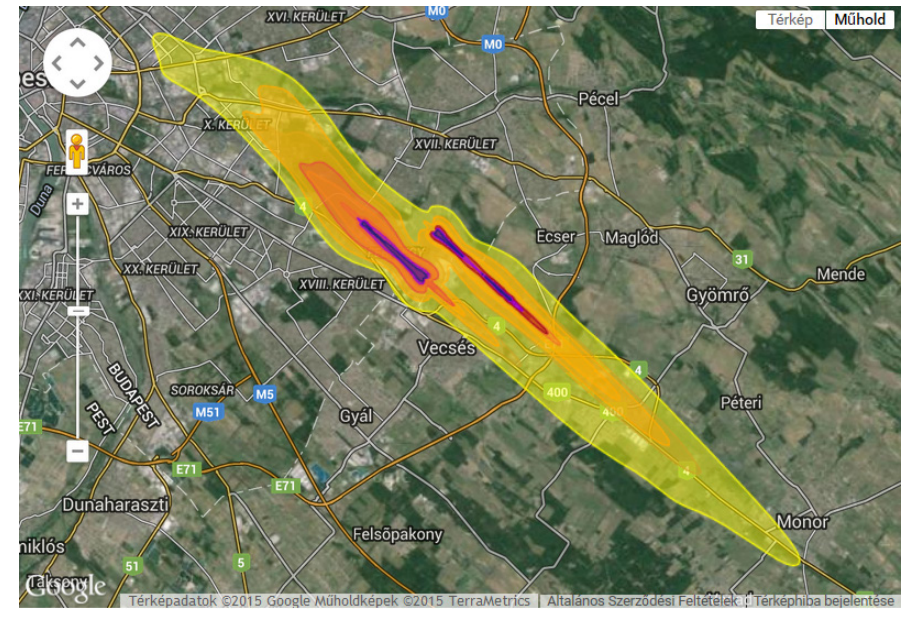

Fig. 1 Location of examined areas and noise isophones of BUD measured in 2014 (source: Budapest Airport)

In Hungary, no public database exists that would contain the relevant property parameters which are necessary for market evaluation. The problem with the public duty imposition database of the National Tax and Customs Administration of Hungary (NTCA) is that it lacks the data required for this study (the ground space of family houses, building quality etc.), and data related to the properties (number of rooms, comfort level etc.) are uploaded quite arbitrarily. For this reason, we chose an advertisement database as the basis of our study. A considerable part of Hungary's current real estate offers can be found on the "ingatlan.com" website. According to the statement published by the company that runs the website (Arkon Zrt.), the portal is a market leader, and a large majority of the market offering can be found there ${ }^{6}$. This statement is also confirmed by the experience of real estate agencies. Based on research ${ }^{7}$, the offer prices in the advertisements and the prices of the actual transactions are closely related. This relation becomes even stronger as the market is being stirred up: offer prices are approaching the actual transaction prices as well. According to the quoted study, in 2014, asking prices exceeded actual transaction prices by $16 \%$ on average in the affected area. Based on the above, we found the database of "ingatlan.com" suitable for this study with certain corrections and remarks which will be explained later. Samples were collected on a single occasion, on 21 September 2015, both for Üllö and Gyömrö: the first 200 items of the daily offer were collected. We picked the category "family house for sale" as a filter. Duplicates were weeded out of the rough sample as follows: if there were more offers for the same property, we kept the data of the later (more up-to-date) advertisement. Furthermore, we also weeded out extremely deviating

6 "Development according to Demand" (“Fejlesztés az igények szerint.") http://info.ingatlan.com/ downloaded on 16/10/2015

7 "Value Map of Residential Properties by OTP Bank" ("OTP Lakóingatlan Értéktérkép") 2014/2, https://www.otpbank.hu/OTP.../Ertekterkep_ Lakoingatlan_2014_2.pdf, downloaded on 16/10/2015. 
and obviously wrong data. At the end, there were 149 items left for the study sample in the case of Gyömrö, and 150 for Üllő.

For each property (record), the following data were extracted from the advertisement database: asking price of a property with family house; spatial measures of buildings; spatial measures of the lot; number of rooms and, if available, location within the settlement. One of the biggest drawbacks of the studied database is that it doesn't enable spatial analysis, because only about a quarter of the advertisements contain descriptive data related to the location (street name). Moreover, based on the experience of agents, even this information is often wrong or misleading. Furthermore, the data, description and photos related to the quality of the properties are of varying quality and quantity for each record. These data were analysed and considered separately for each property, then summarised under a "quality" data category. As a result, the following attributes were included under the "quality" variable: year of building, structure, surfaces, heating method and architectural value. This variable was evaluated on a scale ranging from 1 to 5: 1 being a property in the worst condition (to be demolished), and 5 the best, with excellent technical properties. As a result, the main statistical attributes of the database (managed separately for Üllő and Gyömrö) are as follows (Table 1):

Table 1 Main statistical data of the sample

\begin{tabular}{|c|c|c|c|}
\hline & Ü1lő & Gyömrö & $\begin{array}{l}\text { Üllő+Gyömrő } \\
\text { Total }\end{array}$ \\
\hline Number of items (n) & 150 & 149 & 299 \\
\hline Price (million HUF) Average & 19.84 & 19.61 & 19.72 \\
\hline Price (million HUF) Min & 4.50 & 5.30 & 4.50 \\
\hline Price (million HUF) Max & 63.00 & 45.00 & 63.00 \\
\hline $\begin{array}{l}\text { Price (million HUF) standard } \\
\text { deviation }\end{array}$ & 9.64 & 6.24 & 8.11 \\
\hline Area of property $(\mathrm{m} 2)$ Average & 112.69 & 106.28 & 109.49 \\
\hline Ground space of lot (m2) Average & 763.87 & 694.63 & 729.37 \\
\hline Number of rooms Average & 3.23 & 3.26 & 3.25 \\
\hline Quality Average & 2.88 & 3.10 & 2.99 \\
\hline $\begin{array}{l}\text { Specific price (HUF 000/m2) } \\
\text { Average }\end{array}$ & 186.58 & 199.92 & 193.23 \\
\hline Specific price (HUF 000/m2) Min & 42.96 & 69.13 & 42.96 \\
\hline $\begin{array}{l}\text { Specific price (HUF 000/m2) } \\
\text { Max }\end{array}$ & 372.34 & 350.00 & 372.34 \\
\hline $\begin{array}{l}\text { Specific price (HUF 000/m2) } \\
\text { Standard deviation }\end{array}$ & 59.50 & 57.66 & 58.87 \\
\hline
\end{tabular}

The specific prices in the table were calculated for the ground area of the property, as per the usual practice of the real estate market. The comparison of the specific prices of the two settlements gives grounds for our initial assumption, i.e. the specific average prices in Gyömrö, the town that is not affected by noise load, are $7.1 \%$ higher on average.

\section{Development of the hedonic model}

Variables of the above database were examined in a linear regression analysis as per the hedonic model. Analyses were prepared using the freely downloadable PSPP statistical software package. As a dependent variable, we chose the price, which was also considered an approximation of the market value of each property. Correlation was sought in direct, semi-log and log-log formats, and the log-log correlation had the greatest explanatory power (without transformation $\mathrm{R}^{2}=0.44$; using the natural base logarithm in the semi-log correlation $\mathrm{R}^{2}=0.67$, while describing both dependent and independent variables by natural base logarithm, $\mathrm{R}^{2}=0.73$ ). We therefore applied this model for further analysis. Correlations of similar international studies usually show the explanatory power of the model is between 70 and $90 \%$. The Hungarian analysis of Horváth et al. cited above stated an $\mathrm{R}^{2}$ value of $65-67 \%$, so, we might say our model fits into the row of similar analyses. After running the model, we can see that the ground space of the property and the lot, as well as quality-related variables are decisive, while attributes like the number of rooms, or whether the property is located in Üllő or Gyömrő have no explanatory power. (Table 2).

Table 2 The most important data in the log-log model

\begin{tabular}{|c|c|c|c|c|c|}
\hline & \multicolumn{2}{|c|}{$\begin{array}{l}\text { Unstandardized } \\
\text { Coefficients }\end{array}$} & \multirow{2}{*}{$\begin{array}{c}\begin{array}{c}\text { Standardized } \\
\text { Coefficients }\end{array} \\
\text { Beta }\end{array}$} & \multirow[t]{2}{*}{$\mathrm{t}$} & \multirow[t]{2}{*}{ Sig. } \\
\hline & B & Std. Error & & & \\
\hline (Constant) & -.28 & .18 & .00 & -1.56 & .120 \\
\hline InLAKASTER & .41 & .05 & .43 & 8.14 & .000 \\
\hline InTELEKTER & .08 & .02 & .19 & 5.25 & .000 \\
\hline $\ln S Z O B A$ & .09 & .06 & .08 & 1.66 & .097 \\
\hline $\operatorname{lnMIN}$ & .67 & .04 & .59 & 17.14 & .000 \\
\hline UGYDummy & -.01 & .02 & .01 & -.40 & .691 \\
\hline
\end{tabular}

The final model was acquired by dismissing the number-ofrooms variable, which shows that the difference between the settlements is not significant. (Table 3).

Table 3 The most important data in the final model

\begin{tabular}{lccccc}
\hline & \multicolumn{2}{c}{$\begin{array}{c}\text { Unstandardized } \\
\text { Coefficients }\end{array}$} & $\begin{array}{c}\text { Standardized } \\
\text { Coefficients }\end{array}$ & $\mathrm{t}$ & Sig. \\
\cline { 2 - 4 } & $\mathrm{B}$ & Std. Error & Beta & & \\
\hline (Constant) & -.47 & .14 & .00 & -3.26 & .001 \\
$\ln$ lnLKASTER & .47 & .03 & .50 & 14.51 & .000 \\
$\ln$ lnELEKTER & .08 & .02 & .19 & 5.15 & .000 \\
$\operatorname{lnMIN}$ & .68 & .04 & .60 & 17.34 & .000 \\
UGYDummy & -.01 & .02 & .02 & -.53 & .595 \\
\hline
\end{tabular}

Coefficients (lnERTEK)

Note: $n=299 ; R=0.85 ; R^{2}=0.73$ 
Furthermore, it is clear that the explanatory power of the quality variable is quite high; in fact, it is higher than that of the property's floor area, even though this is practically the only information used for describing the market, as it enables calculation of the specific price. We have made an attempt to link cases related to top category (categories 3, 4 and 5) properties only. (Table 4) The explanatory power of the model is smaller $\left(R^{2}=0.62\right)$, while the significance level of the explanatory variable "location" is decreasing. This change allows us to put a careful assumption, i.e. (as we have seen in international examples) that local noise load may prevail more strongly for higher category properties in this case as well.

Table 4 The most important data in the final model (top category premises)

\begin{tabular}{lccccc}
\hline & \multicolumn{2}{c}{$\begin{array}{c}\text { Unstandardized } \\
\text { Coefficients }\end{array}$} & $\begin{array}{c}\text { Standardized } \\
\text { Coefficients }\end{array}$ & $\mathrm{t}$ & Sig. \\
\cline { 2 - 5 } & $\mathrm{B}$ & Std. Error & Beta & & \\
\hline (Constant) & -.35 & .21 & .00 & -1.68 & .095 \\
lnLAKASTER & .47 & .04 & .65 & 12.39 & .000 \\
$\ln$ lnELEKTER & .07 & .02 & .23 & 4.37 & .000 \\
$\operatorname{lnMIN}$ & .61 & .09 & .33 & 7.17 & .000 \\
UGYDummy & .03 & .03 & .05 & 1.12 & .262 \\
\hline
\end{tabular}

Coefficients (lnERTEK)

Note: $n=199 ; R=0.79 ; R^{2}=0.62$

\section{Conclusion}

Based on the above examination of the model, we might draw the conclusion that the extreme, 25\% value impairment that is commonly assumed is not justified by the sample. Even if such an impact exists at all, it is to a much lesser extent than commonly thought. Even though the presented model describes the relations of the housing market well, the hypothesis mentioned in the introduction, i.e. the separation of noise-laden and noise-free areas, could not be justified. This might have several reasons: beyond the methodological problems explained above (insufficient data e.g. asking prices, spatial data etc.), the reason can be that after the recession, the awakening housing market and its actors are not sensitive or not as sensitive to environment-related impacts as we have seen with actors in the Western European or North American markets. It is an important finding of the study that the quality of the property is an essential descriptive variable. This information is available only arbitrarily in the NTCA database and may be supplemented from advertising websites, even though it can be crucial for similar hedonic models in the future.

On the other hand, the analysis makes it clear that any further investigation on the impact of environment-related variables, including noise, on property prices may only be conducted by appropriate systematic data collection and compilation of suitable databases. A more accurate analysis would require detailed spatial data of each property. By comparing these data with the properties of the areas that fall within the isophones of noisy areas, the magnitude of noise could be introduced into the model. Longer time spans and a regression analysis of them will be required so that the impacts of market changes can be considered and filtered appropriately.

\section{References}

Bell, R. (2001). The Impact of Airport Noise on Residential Real Estate. The Appraisal Journal. 69(3), pp 312-321.

Boes, S., Nüesch, S. (2010). Quasi-experimental evidence on the effect of aircraft noise on apartment rents. Journal of Urban Economics. 69(2), pp. 196-204. https://doi.org/10.1016/j.jue.2010.09.007

Chan, K. W., Chin, T. L. (2002). A Critical Review of Literature on the Hedonic Price Model and Its Application to the Housing Market in Penang. In: The seventh Asian Real Estate Society Conference, Seoul, Korea, Jul. 4-6, 2002. p. 12.

Chaso, C., Le Gallo, J. (2012). The Impact of Objective and Subjective Measures of Air Quality and Noise on House Prices: A Multilevel Approach for Downtown Madrid. Economic Geography. 89(2), pp. 127-148. https://doi.org/10.1111/j.1944-8287.2012.01172.x

Frey, B. S., Luechinger, S., Stutzer, A. (2009). The life satisfaction approach to environmental valuation. CESifo working paper, No. 2836. [Online]. Available from: http://hdl.handle.net/10419/30462. [Accessed: 23 October 2015].

Hajnal, I. (2012). Mobil-adótornyok értékcsökkentő hatása. (The Value-Decreasing Impact of Mobile Transmission Towers.) Magyar Épitöipar. 62(3), pp. 86-91. (in Hungarian)

Herath, S. (2015). How far is too far from public transport? An empirical assessment. In: COBRA AUBEA 2015. Sydney, Jul. 8-10, 2015

Horváth, Á., Székely, G. (2009). Hedonikus módszerek alkalmazása a használt lakások áralakulásának megfigyelésében. (Applying Hedonic Approaches in the Observation of Price Trends of Second Hand Apartments.) Statisztikai Szemle. 87(6), pp. 595-607. (in Hungarian)

Horváth, K., Hajnal, I. (2014). Value Impairment of Contaminated Real Estate. Periodica Polytechnica Social and Management Sciences. 22(2), pp. 141-148. https://doi.org/10.3311/PPso.7389

Jim, C. Y., Chen, W. Y. (2006). Impacts of urban environmental elements on residential housing prices in Guangzhou (China). Landscape and Urban Planning. 78(4), pp. 422-434.

https://doi.org/10.1016/j.landurbplan.2005.12.003

Jud, G. D., Winkler, D. T. (2006). The Announcement Effect of an Airport Expansion on Housing Prices. Journal of Real Estate Finance and Economics. 33(2), pp. 91-103. https://doi.org/10.1007/s11146-006-8943-4

Kain, J. F., Quigley, J. M. (1970). Measuring the Value of Housing Quality. Journal of the American Statistical Association. 65(330), pp. 532-548.

Kugler, Sz., Munkácsi, Zs., Szarvas, G., Galyas, R. (2010). A ferihegyi repülőtér környezeti hatásainak vizsgálata az izlandi vulkáni tevékenység következtében elrendelt légtérzár időszakában. (An Examination of the Environmental Impacts of Budapest Airport During the Full Flight Ban Ordered because of the Icelandic Volcano Eruption.) In: XVII. Repüléstudományi Napok. Nov. 11-12, 2010, Budapest. (in Hungarian)

Lazic, A., Golaszewski, R. (2006). A Technical Note on Aircraft Noise and its Cost to Society. GRA Incorporated, Economic Counsel to the Transportation Industry. 2006. p. 7.

Malpezzi, S. (2003). Hedonic pricing models: a selective and applied review. In: Housing Economics and Public Policy. O’Sullivan, T., Gibb, K. (eds.), Blackwell Science, Oxford, pp. 67-89. https://doi.org/10.1002/9780470690680.ch5 
Miedema, H., Oudshoorn, C. (2001). Annoyance from Transportation Noise: Relationships with Exposure Metrics DNL and DENL and Their Confidence Intervals. Environmental Health Perspectives. 109(4), pp. 409-416.

Morancho, A. B. (2003). A hedonic valuation of urban green areas. Landscape and Urban Planning. 66(1), pp. 35-41.

https://doi.org/10.1016/S0169-2046(03)00093-8

Munkácsi, Zs., Muntag, A., Pávó, Gy., Weidinger, T., Szarvas, G. (2010). A légiközlekedési zaj tulajdonságai és terjedésének vizsgálata BudapestFerihegy Nemzetközi Repülőtér környezetében. (An Examination of the Characteristics and Spread of Flight Noise in the Proximity of Budapest International Airport.) Repüléstudományi Közlemények. 22(2), pp. 209216. (in Hungarian)

Nelson, J. P. (2004). Meta-analysis of airport noise and hedonic property values: Problems and prospects. Journal of Transport Economics and Policy. 38(1), pp 1-28.
Nelson, J. P. (2008). Hedonic Property Value Studies of Transportation Noise: Aircraft and Road Traffic. In: Hedonic Methods in Housing Markets, Pricing Environmental Amenities and Segregation. Baranzini, A. Ramirez, J., Schaerer, C. (eds.) Springer, 2008.

Thamrongsrisook, C. (2011). The Influence of Rapid Transit Systems on Condominium Prices in Bangkok. A Hedonic price model approach. Master Thesis, KTH University, Stockholm, 2011.

Valdes, C. (2008). Comparing methodologies that correlate property values and airport noise. Master's Thesis and Graduate Research. San Jose University, 2008. p. 66. 